\title{
Net accumulation rates derived from ice core stable isotope records of Pío XI glacier, Southern Patagonia Icefield
}

\author{
M. Schwikowski ${ }^{1,2,3}$, M. Schläppi ${ }^{1,2,3}$, P. Santibañez ${ }^{4}$, A. Rivera ${ }^{4,5}$, and G. Casassa \\ ${ }^{1}$ Paul Scherrer Institut (PSI), Villigen, Switzerland \\ ${ }^{2}$ Department for Chemistry and Biochemistry, University of Bern, Switzerland \\ ${ }^{3}$ Oeschger Centre for Climate Change Research, University of Bern, Switzerland \\ ${ }^{4}$ Centro de Estudios Científicos (CECS), Valdivia, Chile \\ ${ }^{5}$ Departamento de Geografía, Universidad de Chile, Santiago, Chile
}

Correspondence to: M. Schwikowski (margit.schwikowski@psi.ch)

Received: 28 November 2012 - Published in The Cryosphere Discuss.: 19 December 2012

Revised: 30 July 2013 - Accepted: 16 August 2013 - Published: 25 October 2013

\begin{abstract}
Pío XI, the largest glacier of the Southern Patagonia Icefield, reached its neoglacial maximum extent in 1994 and is one of the few glaciers in that area which is not retreating. In view of the recent warming it is important to understand glacier responses to climate changes. Due to its remoteness and the harsh conditions in Patagonia, no systematic mass balance studies have been performed. In this study we derived net accumulation rates for the period 2000-2006 from a $50 \mathrm{~m}$ (33.2 $4 \mathrm{~m}$ weq) ice core collected in the accumulation area of Pío XI (2600 m a.s.1., 49 $16^{\prime} 40^{\prime \prime} \mathrm{S}$, $\left.73^{\circ} 21^{\prime} 14^{\prime \prime} \mathrm{W}\right)$. Borehole temperatures indicate near temperate ice, but the average melt percent is only $16 \pm 14 \%$. Records of stable isotopes are well preserved and were used for identification of annual layers. Net accumulation rates range from 3.4-7.1 water equivalent ( $\mathrm{m}$ weq) with an average of $5.8 \mathrm{~m}$ weq, comparable to precipitation amounts at the Chilean coast, but not as high as expected for the Icefield. Ice core stable isotope data correlate well with upper air temperatures and may be used as temperature proxy.
\end{abstract}

\section{Introduction}

The Southern Patagonia Icefield (SPI) is the largest ice body of the Southern Hemisphere outside Antarctica with an area of $13000 \mathrm{~km}^{2}$ and 48 major glaciers (Aniya et al., 1996), many of them calving into fjords and lakes. Since the end of the Little Ice Age (LIA, late 19th Century) most of the Patagonian glaciers have been retreating and thinning, con- tributing significantly to sea-level rise (Glasser et al., 2011), with only a few in a state of equilibrium or advance (Casassa et al., 2002; Masiokas et al., 2009a, b). Glacier retreat is interpreted primarily as a response to regional atmospheric warming and to a lesser extent to precipitation decrease (Casassa et al., 2002). Among the advancing ones is Pío XI (also called Brüggen), the largest glacier of SPI with a length of 65.7 and $1277 \mathrm{~km}^{2}$ total area in 2003 . This glacier has the longest record of frontal variation observations in the SPI and reached its neoglacial maximum extent in 1994, when it destroyed mature 400 yr old trees (Rivera et al., 1997a; Warren and Rivera, 1994; Rivera and Casassa, 1999). Between 1995 and 1999 Pío XI was relatively stable with an overall minor retreat. By 2000 the glacier readvanced again, reaching a position close to the 1994-maximum extent in 2008 (Masiokas et al., 2009b). The anomalous behaviour of Pío XI has been attributed to a surging (Rivera and Casassa, 1999; Rivera et al., 1997b). The reaction of Pío XI is probably a good example of the well known Tidewater Calving Glacier Cycle (TWG) (Post et al., 2011), not only described in Alaska (Pelto and Miller, 1990), but more recently at Glaciar Jorge Montt also in Patagonia (Rivera et al., 2012). Jorge Montt and Pío XI glaciers, in spite of both being located at the SPI, are however in the very opposite phase of the TWG, as the former is probably ending the fastest retreat phase, while the latter is in the steady state phase after an advancing cycle that started in 1944/45 (Rivera et al, 1997a). Since 1994 Pío XI has been quite stable, which is very likely explained by a combination of factors including hypsometry 
(Rivera and Casassa, 1999), low bathymetry near the present front due to a new pushing moraine and associated outwash plain (sandur) created by the glacier advance (Warren and Rivera, 1994), a surging behaviour (Rivera et al, 1997a), and a positive mass balance of the glacier in the last decades (Rignot et al., 2003). Nevertheless, a recent study suggests that the glacier is more likely thinning as a whole, indicating that the advance of Pío XI is unlikely to be sustained (Willis et al., 2012).

Considering recent warming in Southern Patagonia and the Antarctic Peninsula it is important to understand glacier variations and their responses to climate change (Cook et al., 2005; Rosenblüth et al., 1995; Thomas et al., 2009). A quick response to climate change is expected for glaciers with high accumulation and ablation rates (Oerlemans and Fortuin, 1992). However, changes of equilibrium line altitude (ELA), front, volume, and ice thickness have so far only be deduced from maps, aerial photos, and satellite data. No systematic glacier mass balance or other in-situ data have been obtained yet from Pío XI glacier.

The climate of the SPI is dominated by prevailing intense Westerlies, which are slightly stronger in summer compared to winter (Carrasco et al., 2002). They continuously carry humid air masses from the Pacific Ocean towards the Andes which form an efficient barrier from North to South, resulting in a strong west-east gradient of precipitation with about $7000 \mathrm{~mm}$ per year on the Chilean coast and less than $200 \mathrm{~mm}$ east of the Andes (Carrasco et al., 2002; Schneider et al., 2003; Villalba et al., 2003). At the Chilean coast more than 300 days of rain per year were observed and mean annual cloudiness exceeds $85 \%$ (Warren and Sugden, 1993). Phenomena like El Niño have minor influence on the Patagonian climate (Warren and Sugden, 1993). Extreme weather conditions were recorded during an ice drilling expedition on Tyndall glacier, SPI, with wind speeds of $13.6 \mathrm{~m} \mathrm{~s}^{-1}$ (hourly average, measured over $24 \mathrm{~h}, 1756 \mathrm{~m}$ a.s.l.), snow accumulation of $3.5 \mathrm{~m}$ ( $1.75 \mathrm{~m}$ weq) within 24 days from 30 November to 23 December 1999 , and visibility of more than $50 \mathrm{~m}$ only on 4 out of 24 days (Kohshima et al., 2007).

Precipitation and temperature data required to understand glacier responses are available only from coastal sites or east of SPI. Weather stations show homogenous distribution of precipitation throughout the year (Carrasco et al., 2002) with a decreasing trend for Lago Argentino (period 1940-1990) (Ibarzabal et al., 1996), Puerto Montt (1961-2005) and Coyhaique (1961-2005) (Carrasco et al., 2008). Only for Punta Arenas a slight increase of precipitation is reported for the period 1965-2005 (Carrasco et al., 2008). No longer-term data is available between 48 and $52^{\circ} \mathrm{S}$, the latitude of SPI.

Temperature is like precipitation, poorly documented in this region. West of SPI typical maritime influence with small seasonal but high annual variations is observed, whereas east of SPI more continental climate with larger temperature fluctuation during the year prevails (Rosenblüth et al., 1995). Minimum temperatures for the period 1961-2006 show a slight warming south of $47^{\circ} \mathrm{S}$ and a cooling of 0.04 to $0.18^{\circ} \mathrm{C}$ per $10 \mathrm{yr}$ between 40 and $47^{\circ} \mathrm{S}$. Most of these tendencies were attributed to the 1976/77 climate shift (Carrasco et al., 2008). For the more recent period 1979-2006, temperature trends over land in southern Chile $\left(38-48^{\circ} \mathrm{S}\right)$ are weak and show no clear spatial patterns (Falvey and Garreaud, 2009). At higher altitude ( $850 \mathrm{hPa})$, NCEP-NCAR reanalysis data reveal a warming trend of $0.5^{\circ} \mathrm{C}$ over $40 \mathrm{yr}$, both in winter and summer, resulting in a shift from snow to rain of $\sim 5 \%$ of the precipitation, whereas the total amount has changed little (Rasmussen et al., 2007).

In principle, an accumulation history can be obtained from glacier ice cores, but only few cores with meaningful climatic information have been obtained from Patagonia. This deficiency is due to extremely harsh field conditions with stormy weather and high precipitation rates throughout the year, and to the fact that the low-altitude main plateaus of both the Northern Patagonia Icefield (NPI) and the SPI are strongly influenced by meltwater percolation. Meltwater may cause a loss of climatic signal, which was reported for the lower plateau area of NPI and SPI, e.g. at San Rafael glacier, 1296 m a.s.l. (Yamada, 1987), Nef glacier, $1500 \mathrm{~m}$ a.s.l. (Matsuoka and Naruse, 1999), and Tyndall glacier, $1756 \mathrm{~m}$ a.s.l. (Shiraiwa et al., 2002). Accumulation rates of several metres of snow per year were deduced from the preserved part of the stable isotope record, but they are representative only for the year before drilling.

There are a few high-elevated $(>2000 \mathrm{~m})$ potential drilling sites on mountains in the Icefields, and from three of them shallow cores were collected. Records from Perito Moreno glacier (Aristarain and Delmas, 1993), Gorra Blanca Norte (Schwikowski et al., 2006), and San Valentín (Vimeux et al., 2008) showed well preserved chemical and stable isotope signals, less perturbed by melting. Net snow accumulation rates are lower at higher elevated drilling sites, with $1.2 \mathrm{~m}$ weq at Perito Moreno $\left(2000 \mathrm{~m}, 50^{\circ} 38^{\prime} \mathrm{S}, 73^{\circ} 15^{\prime} \mathrm{W}\right.$, SPI), $1 \mathrm{~m}$ weq at Gorra Blanca Norte $\left(2300 \mathrm{~m}, 49^{\circ} 8^{\prime} \mathrm{S}\right.$, $73^{\circ} 3^{\prime} \mathrm{W}, \mathrm{SPI}$ ), and $0.19 \mathrm{~m}$ weq at San Valentín $(3747 \mathrm{~m}$, $\left.46^{\circ} 35^{\prime} \mathrm{S}, 73^{\circ} 19^{\prime} \mathrm{W}, \mathrm{NPI}\right)$. All three sites are located east of the ice divide of the Icefields, where lower precipitation rates are expected, but nonetheless, there might be net loss by erosion due to the intense winds (Vimeux et al., 2011).

In this regard, the upper reaches of Pío XI glacier appear to be an excellent candidate to obtain net accumulation information, because they are located at an altitude where little influence of melting expected, and where wind erosion should not be so critical, since it forms an extended, gently sloping plateau. In August 2006 a $50 \mathrm{~m}$ ice core was drilled in the accumulation area $\left(49^{\circ} 16^{\prime} \mathrm{S}, 73^{\circ} 21^{\prime} \mathrm{W}, 2600 \mathrm{~m}\right.$ a.s.l.).

In the present study the characteristics of the glacier and the ambient climate are investigated. The potential of the glacier for ice core-based reconstruction of accumulation and temperature is discussed. 


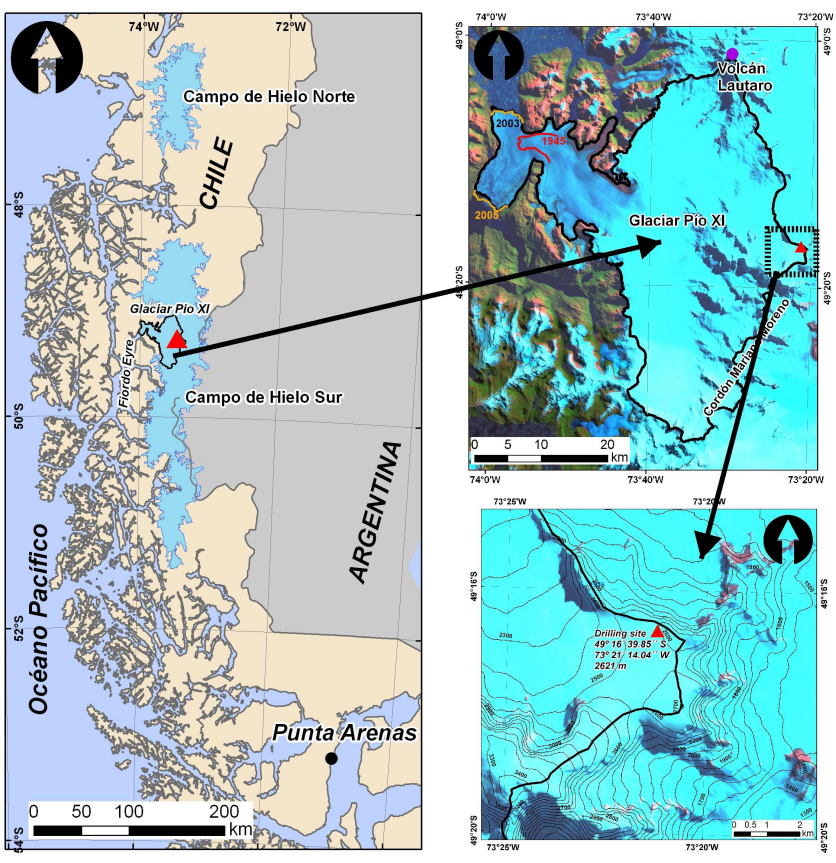

Fig. 1. Left: Map of Southern South America with Northern Patagonia Ice Field (NPI, Campo de Hielo Norte) and location of Pío XI glacier at the Southern Patagonia Ice Field (SPI, Campo de Hielo Sur). The red triangle marks the drilling site. Upper right: Landsat ETM, acquired on 2 April 2003, showing the area of Pío XI glacier with ice front position in 1945 (red line), 2003 (black), and 2005 (orange). Lower right: The northern plateau of Cordón Mariano Moreno including topographic information (contour lines) extracted from SRTM.

\section{Sampling site and methods}

\subsection{Expedition and sampling site}

Based on glacier topography, results from a first study in 2001 (Schwikowski et al., 2006), and a reconnaissance flight on 14 April 2006, the northern plateau of Cordón Mariano Moreno (CMM) was selected for ice coring $\left(49^{\circ} 16^{\prime} 40^{\prime \prime} \mathrm{S}\right.$, $73^{\circ} 21^{\prime} 14^{\prime \prime} \mathrm{W}, 2600 \mathrm{~m}$ a.s.l., Figs. 1 and 2 ). The site is part of the accumulation area of Pío XI glacier. A possible escape route allowing descending the glacier on skis autonomous from helicopter in case of bad weather conditions was also explored during the reconnaissance flight.

Drilling camp was set up on 19 August 2006 at a location, where a radar survey with a $6 \mathrm{MHz}$ system indicated glacier thicknesses of $170 \mathrm{~m}$. On the northern CMM plateau glacier thickness varied from 70 to more than $300 \mathrm{~m}$. Drilling was performed with an updated version of the electromechanical drill described by Ginot et al. (2002) producing cores with a diameter of $8.2 \mathrm{~cm}$ and a maximum core length of $75 \mathrm{~cm}$. The drill was operated in a particularly rigid tent which was developed for harsh field conditions. This tent, manufactured by FS INVENTOR AG Switzerland, consists
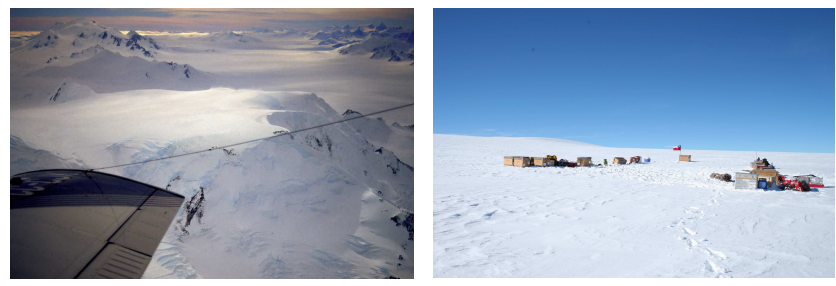

Fig. 2. Left: photo of the northern plateau of Cordón Mariano Moreno with Volcán Lautaro in the background (photo Andrés Rivera during the reconnaissance flight on 14 April 2006). Right: drilling site on the plateau before camp installation (photo Beat Rufibach).

of an aluminium frame and a plasticized canvas cover. It was easy to set up and resisted the strong winds in Patagonia. After two days of drilling a depth of $50.6 \mathrm{~m}$ was reached. At this depth temperate ice containing slight amounts of liquid water was encountered and drilling had to be stopped because of problems with the transport of drilling chips. Borehole temperatures were measured every $10 \mathrm{~m}$ with a temperature probe fixed to the drive unit of the ice drill. The temperature probe was equipped with a PT100 sensor incorporated in an aluminium disc which was in contact with the ice. The probe was connected to a transmitter which generated a signal between 4 and $20 \mathrm{~mA}$, where $4 \mathrm{~mA}$ corresponded to a temperature of $-50^{\circ} \mathrm{C}$ and $20 \mathrm{~mA}$ to a temperature of $+10^{\circ} \mathrm{C}$, respectively (all components from Greisinger Electronic GmbH, Germany, D. Stampfli, personal communication, 2006). A network of nine stakes was set up around the drilling site, where detailed surface topography was measured with a dual-frequency GPS receiver. Stake heights, which were initially $1 \mathrm{~m}$ high at the most, were remeasured after 10 days, at the end of the campaign. Due to heavy snow storms and high wind speeds the drilling camp could not be evacuated before 2 September 2006. The ice core was shipped frozen to the Paul Scherrer Institut.

\subsection{Ice core analyses}

Overall the quality of the ice cores was good. Few of the cores broke into two sections during transport with the freezer truck on the way from Villa O'Higgins to Santiago (ca. $2000 \mathrm{~km}$ ). Processing of the ice core segments was performed in a cold room $\left(-20^{\circ} \mathrm{C}\right)$ at the Paul Scherrer Institut. All cores were weighed, length and diameter were measured to determine density, and stratigraphic features were recorded. To avoid any possible contamination a band saw with a stainless steel blade and a Teflon-coated table was used to cut out inner segments of the ice core (Eichler et al., 2000). Sample resolution varied from 3-6.7 cm, with the larger values at the top to obtain sufficient material for chemical analysis and reduced values towards the bottom with increased density, resulting in average resolution of $4.7 \mathrm{~cm}$. The melt percent profile was generated with the same $4.7 \mathrm{~cm}$ 
average resolution on the samples cut for stable isotope and chemical analysis. Melt features appear bright and bubblefree when the core is backlit. Classes of melt of 0, 25, 50, 75, and $100 \%$ were attributed when the $4.7 \mathrm{~cm}$ sample showed the corresponding percentage of melt. This is equivalent to melt layer thicknesses of $0,1.2,2.4,3.5$, and $4.7 \mathrm{~cm}$, respectively. Since this procedure is subjective and not so precise we averaged the melt percent over $1 \mathrm{~m}$ core length (Fig. 3). Samples were melted at room temperature. Analysis of major ion concentrations and stable isotopes were conducted at Paul Scherrer Institut, Switzerland, whereas biovolume and pollen concentration was determined at Centro de Estudios Científicos, Valdivia, Chile.

The stable isotope ratio $\delta^{18} \mathrm{O}$ was measured by injecting samples in a high temperature $\left(1250^{\circ} \mathrm{C}\right)$ reactor, where water is pyrolysed to carbon monoxide (CO) and transported to the mass spectrometer (Finnigan Delta Plus XP) using helium as carrier gas (Gehre et al., 2004). For $\delta \mathrm{D}$ determination the sample was reduced in a chromium reactor prior to mass spectrometric analysis (Finnigan Mat Delta S) (Nelson and Dettman, 2001). $\delta \mathrm{D}$ and $\delta^{18} \mathrm{O}$ values are reported in permil deviation of the isotope ratio to an internationally accepted standard (Vienna Standard Mean Ocean Water, VSMOW). For calibration and correction for instrument drifts, two in-house standards were used $\left(\delta^{18} \mathrm{O}=-9.82\right.$ and $-20 \%, \delta \mathrm{D}=-70.3$ and $-162 \%$, respectively) which were calibrated against the IAEA reference standard. Precision was $0.1 \%$ for $\delta^{18} \mathrm{O}$ and $0.5 \%$ for $\delta \mathrm{D}$. Major ions were analysed using standard ion chromatography.

Ice core samples for biological analysis were cut in $20 \mathrm{~cm}$ sections from 0 to $40 \mathrm{~m}$, and $10 \mathrm{~cm}$ sections from 40 to $50 \mathrm{~m}$, after removing $0.5 \mathrm{~cm}$ of the core surface for eliminating potential contaminants. Sample preparation was conducted according to Santibanez et al. (2008). Microalgae and pollen grains were counted using a fluorescent microscope (OLYMPUS BX-FLA). The total cell number of microalgae and pollen of Nothofagus spp. was estimated on each filter by counting the cells along five to seven parallel transects. In the case of Podocarpaceae, all pollen grains present were counted.

\section{Results and discussion}

\subsection{Borehole temperatures and density profile}

Temperatures measured in the borehole were just slightly below $0{ }^{\circ} \mathrm{C}$, indicating near temperate ice (Fig. 3). Annual mean air temperature at $700 \mathrm{hPa}$, an altitude roughly corresponding to $2850 \mathrm{~m}$, for the period $2001-2007$ was $-8.2{ }^{\circ} \mathrm{C}$, ranging from -0.36 to $-12.44^{\circ} \mathrm{C}$ (monthly values, grid $49.5^{\circ} \mathrm{S}$, $73.5^{\circ} \mathrm{W}$, ERA-Interim). The elevated ice temperature indicates input of latent heat from refreezing of surface melt water formed in summer. Ice lenses from $0.1-19 \mathrm{~cm}$ thickness, formed by refreezing, are present throughout the core, but

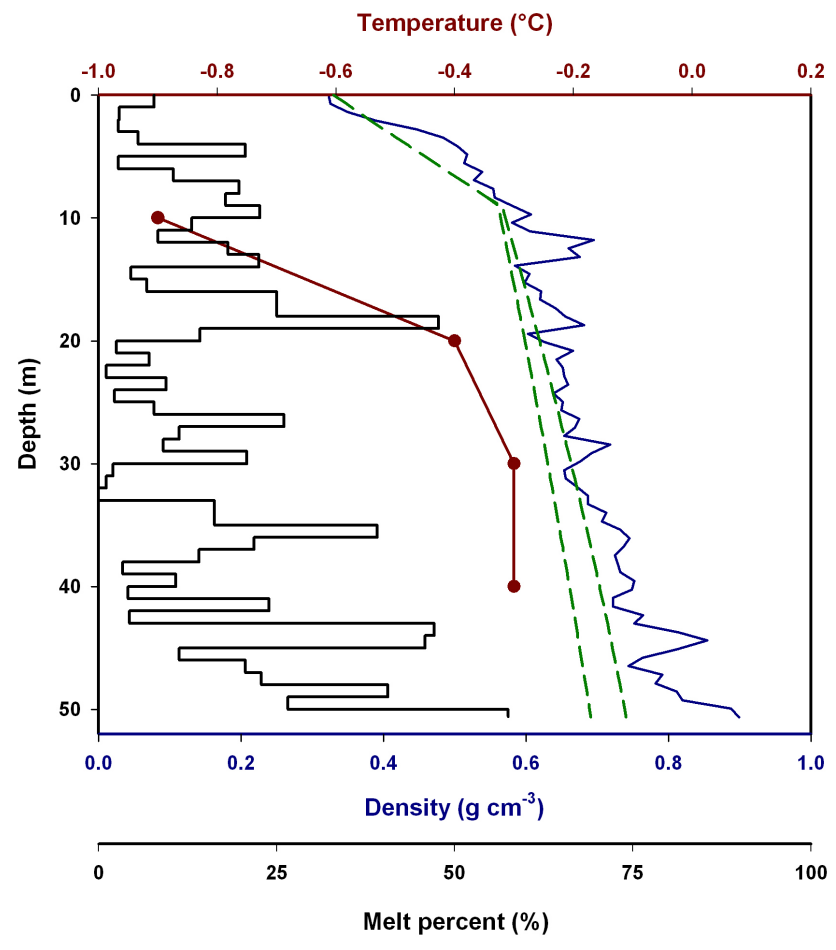

Fig. 3. Density profile (blue), temperature (red) in the borehole at Pío XI glacier, and melt percent (black). The melt percent represents averages over $1 \mathrm{~m}$ depth. Green dashed lines show densities simulated with an empirical model of firn densification in the dry firn zone (Herron and Langway, 1980), using a firn temperature of $-1^{\circ} \mathrm{C}$ and an annual accumulation rate of $7.1 \mathrm{~m}$ weq (left curve) and $3.4 \mathrm{~m}$ weq (right curve), respectively.

alternate with pure firn. Most of the ice lenses were thin, with 338 ice lenses having a thickness of about $1 \mathrm{~cm}$ (class $25 \%$ ) out of a total number of 478 . The number of ice lenses per metre depth varied from 0 at $32 \mathrm{~m}$ depth to 24 at $44 \mathrm{~m}$ depth. The corresponding melt percent averaged over $1 \mathrm{~m}$ depth ranges from $0-58 \%$ with a mean value of $16 \pm 14 \%$ (Fig. 3). Latent heat released by freezing of one gram of water raises the temperature of $160 \mathrm{~g}$ of snow by one degree (Cuffey and Paterson, 2010). A simple estimation based on mean values of the entire core suggests that the latent heat release due to the observed amount of ice lenses would result in warming by $8.7^{\circ} \mathrm{C}$ (mean density: $0.66 \mathrm{~g} \mathrm{~cm}^{-3}$, total snow mass per $\mathrm{cm}^{-2}: 3340 \mathrm{~g}$, total ice mass formed by refreezing of melt water: $182 \mathrm{~g} \mathrm{~cm}^{-2}$ (refrozen melt water filling the pore space of $0.66 \mathrm{~g} \mathrm{~cm}^{-3}$ dense firn)). The resulting warming is in the order of magnitude needed to explain the difference between the estimated annual mean air temperature and the measured borehole temperatures.

The density increases from $0.32 \mathrm{~g} \mathrm{~cm}^{-3}$ at the surface to $0.90 \mathrm{~g} \mathrm{~cm}^{-3}$ at $50.6 \mathrm{~m}$ depth with an average value of $0.66 \mathrm{~g} \mathrm{~cm}^{-3}$ (Fig. 3). This indicates that the firn-to-ice transition was probably reached at a depth of $50.6 \mathrm{~m}$, which would explain the observed small amounts of liquid water at this 


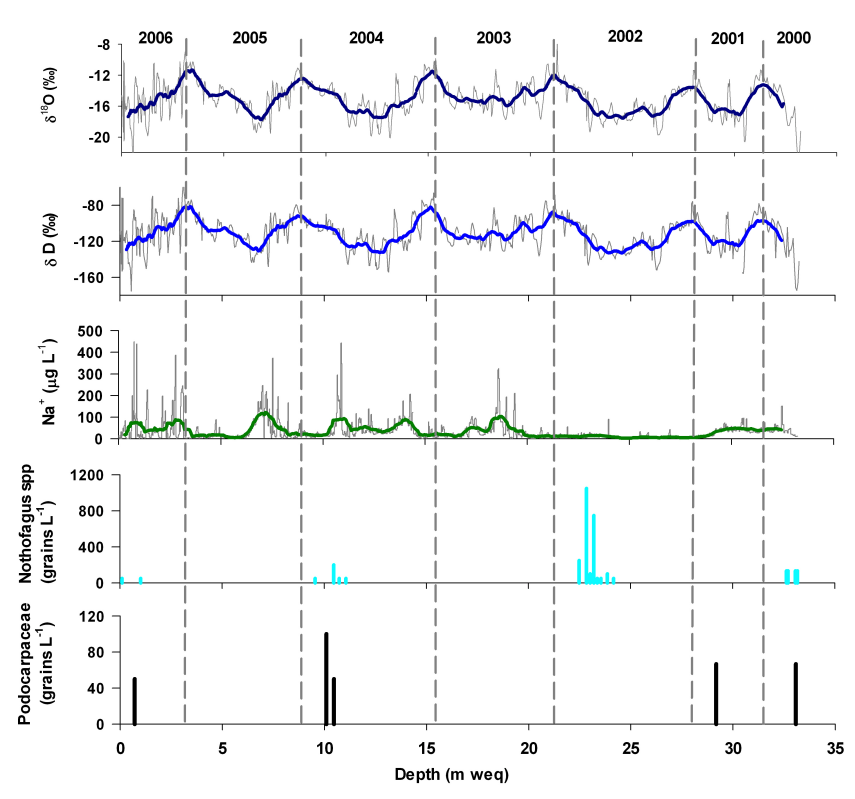

Fig. 4. Pío XI ice core stable isotope ratios $\delta^{18} \mathrm{O}, \delta \mathrm{D}$ (raw data and 29 point moving average), $\mathrm{Na}^{+}$concentration (raw data and 29 point moving average), and pollen records. Proposed attribution of years is indicated with vertical dashed lines.

depth. However, the radar data collected on site were not clear enough to see a continuous internal layer associated to a possible water table. Densities are slightly higher than simulated with a simple empirical model for pure firn densification in the dry firn zone (Herron and Langway, 1980), especially in the sections where melt percentages exceed $20 \%$ (Fig. 3). Nevertheless, there is still a big difference to the profiles of glaciers with superimposed ice, which approach an ice density of $0.917 \mathrm{~g} \mathrm{~cm}^{-3}$ in the topmost metres (e.g. Matsuoka and Naruse, 1999). The melt-free firn somehow follows the envelope of the two simulations, but the data is not precise enough to conclude which is the better representation. Compared to temperate glaciers, the firn-ice transition at Pío XI occurs at greater depths, suggesting that this part of the glacier belongs to the percolation zone using the classification scheme of Cuffey and Paterson (2010).

\subsection{Stable isotope ratios and net accumulation rates}

Stable isotope ratios $\delta^{18} \mathrm{O}$ and $\delta \mathrm{D}$ in the Pío XI core fluctuate regularly around a mean value of $-15.1 \pm 2.2 \%$ ofor $\delta^{18} \mathrm{O}$ and $-111.2 \pm 18.1 \%$ for $\delta \mathrm{D}$, respectively (Fig. 4). Amplitudes between maximum and minimum values are similar throughout the core, indicating that the $\delta^{18} \mathrm{O}$ and $\delta \mathrm{D}$ records are not significantly affected by meltwater percolation, consistent with the low average melt percent of $16 \%$. Melting leads in the extreme case to a total loss of signal variability in a depth of a few metres as observed for other ice cores from Patagonia (Matsuoka and Naruse, 1999) or to a reduction of the amplitude in the seasonal stable isotope variation. The latter

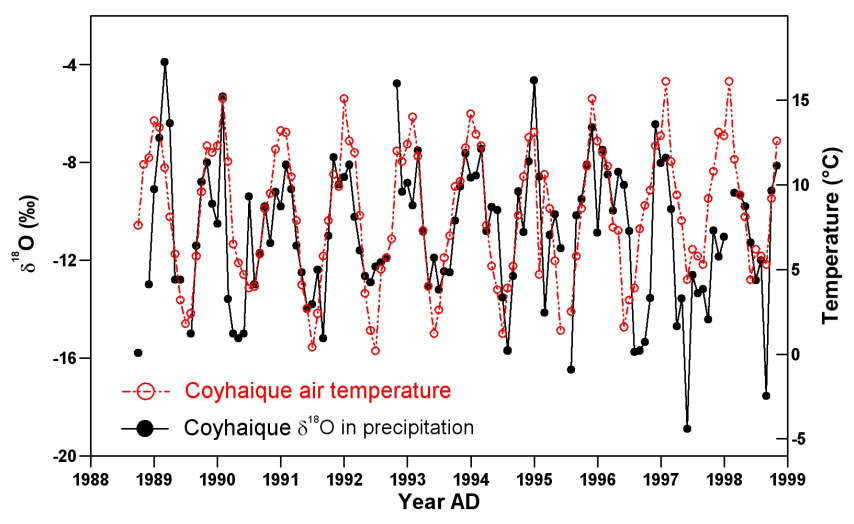

Fig. 5. Relationship between $\delta^{18} \mathrm{O}$ in precipitation and air temperature at the GNIP station Coyhaique $\left(45^{\circ} 21^{\prime} 00^{\prime \prime} \mathrm{S}, 72^{\circ} 4^{\prime} 12^{\prime \prime} \mathrm{W}\right.$, $310 \mathrm{~m}$ a.s.1.) (IAEA/WMO, 2006).

was reported for ice cores from the Arctic with average melt percent values of $40 \%$ (Goto-Azuma et al., 2002) and $55 \%$ (Pohjola et al., 2002), significantly exceeding the amount of melt observed in the Pío XI core. The stable isotope ratios $\delta^{18} \mathrm{O}$ and $\delta \mathrm{D}$ in the Pío XI core show significant correlation $\left(\delta \mathrm{D}=8.0 \times \delta^{18} \mathrm{O}+9.2, r=0.98, n=1078\right)$ and the slope and intercept are in good agreement with the Global Meteoric Water Line $\left(\delta \mathrm{D}=8 \times \delta^{18} \mathrm{O}+10\right)$, pointing to a direct marine origin of precipitation and no continental influence. This good agreement is another indicator for a well-preserved stable isotope record, since melting and refreezing cycles cause a decrease of the slope (Zhou et al., 2008). From the Global Network of Isotopes in Precipitation (GNIP) it is known that in the southern temperate zone of South America (south of $40^{\circ} \mathrm{S}$ ), like in the northern, the isotopic composition of precipitation is controlled mainly by changes in temperature, with a maximum of $\delta^{18} \mathrm{O}$ and $\delta \mathrm{D}$ during austral summer and a minimum during winter (Rozanski and Araguas Araguas, 1995). This relationship between stable isotopes in precipitation and air temperature is illustrated in Fig. 5 on the example of the GNIP station Coyhaique $\left(45^{\circ} 21^{\prime} 00^{\prime \prime} \mathrm{S}\right.$, $72^{\circ} 4^{\prime} 12^{\prime \prime} \mathrm{W}, 310 \mathrm{~m}$ a.s.l.) (IAEA/WMO, 2006) which has the longest record in vicinity of the Southern Patagonia Icefield. Studies of the stable isotope-air temperature relation with a general circulation model (LMDZ4) confirmed this significant positive correlation for Patagonia (Risi et al., 2010). Precipitation in South America is maximal around $50^{\circ} \mathrm{S}$, with over 300 days of rainfall per year in some places (Kerr and Sugden, 1994). The amount of precipitation is nearly uniformly distributed throughout the year (Carrasco et al., 2002) as illustrated in Fig. 6 on the example of the coastal stations Cabo Raper ( $46^{\circ} 48^{\prime} 12^{\prime \prime}$ S, $75^{\circ} 38^{\prime} 17^{\prime \prime}$ W, 46 m a.s.l.), San Pedro $\left(47^{\circ} 43^{\prime} 0^{\prime \prime} \mathrm{S}, 74^{\circ} 55^{\prime} 0^{\prime \prime} \mathrm{W}, 56 \mathrm{~m}\right.$ a.s.l.), and Faro Evangelista $\left(52^{\circ} 24^{\prime} 0^{\prime \prime} \mathrm{S}, 75^{\circ} 6^{\prime} 0^{\prime \prime} \mathrm{W}, 52 \mathrm{~m}\right.$ a.s.l.). We therefore assume that the major fluctuations of $\delta^{18} \mathrm{O}$ and $\delta \mathrm{D}$ in the Pío XI ice core do reflect seasonal temperature variations and can be used to identify annual layers as suggested in Fig. 4. Accord- 


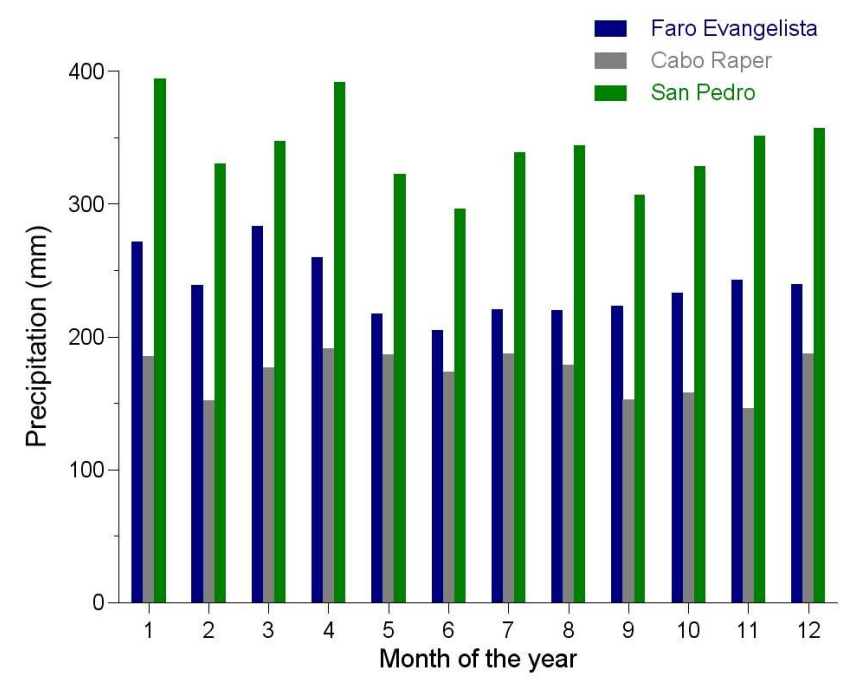

Fig. 6. Monthly averaged precipitation at the coastal sites Cabo Raper $\left(46^{\circ} 48^{\prime} 12^{\prime \prime} \mathrm{S}, 75^{\circ} 38^{\prime} 17^{\prime \prime} \mathrm{W}, 46 \mathrm{~m}\right.$ a.s.1., period $\left.1968-2003\right)$, San Pedro $\left(47^{\circ} 43^{\prime} 0^{\prime \prime} \mathrm{S}, 74^{\circ} 55^{\prime} 0^{\prime \prime} \mathrm{W}, 56 \mathrm{~m}\right.$ a.s.l., period $1968-$ 2003), and Faro Evangelista $\left(52^{\circ} 24^{\prime} 0^{\prime \prime} \mathrm{S}, 75^{\circ} 6^{\prime} 0^{\prime \prime} \mathrm{W}, 52 \mathrm{~m}\right.$ a.s.1., period 1899-2003).

ingly the ice core covers the period winter 2000 to winter 2006. $\delta^{18} \mathrm{O}$ and $\delta \mathrm{D}$ maxima are attributed to February, generally the month with the highest temperatures as indicated by $700 \mathrm{hPa}$ temperature data from Punta Arenas and ERAInterim, see below.

Concentration records of major ions support the proposed attribution of annual layers and the assumption of limited melt. They are preserved in the upper part (years 2006-2003, corresponding to $0-22 \mathrm{~m}$ weq depth) and influenced by percolation only in the lower part. The concentration of $\mathrm{Na}^{+}$is shown as example in Fig. 4. In the preserved part, sea salt components $\mathrm{Na}^{+}, \mathrm{Cl}^{-}, \mathrm{Mg}^{2+}$, and $\mathrm{SO}_{4}^{2-}$ are significantly correlated ( $r$ between 0.60 and 0.92 for logarithmic values) and show the expected seasonality with enhanced concentrations in austral winter related to higher wind speeds in the source area.

Average algal biovolume in the Pío XI core is only $43 \mathrm{~mm}^{3} \mathrm{~mL}^{-1}$ (range $0-590 \mathrm{~mm}^{3} \mathrm{~mL}^{-1}$ ) which is two to three orders of magnitude lower than values found at other glacier sites (Kohshima et al., 2007; Santibanez et al., 2008; Uetake et al., 2006; Yoshimura et al., 2000). Thus it was impossible to derive seasonal boundaries based on algal biovolume. Nothofagus and Podocarpaceae pollen concentrations are also low, but nevertheless they show four maxima each, corresponding closely to the summer maxima identified in the $\delta^{18} \mathrm{O}$ and $\delta \mathrm{D}$ records (Fig. 4). Pollen peaks occur generally earlier than the $\delta^{18} \mathrm{O}$ maxima attributed to February, which is reasonable considering that flowering starts during the austral spring (Hechenleitner et al., 2005). Pollen was not detected in every spring season identified in the stable isotope records. The absence of pollen during a particular spring-

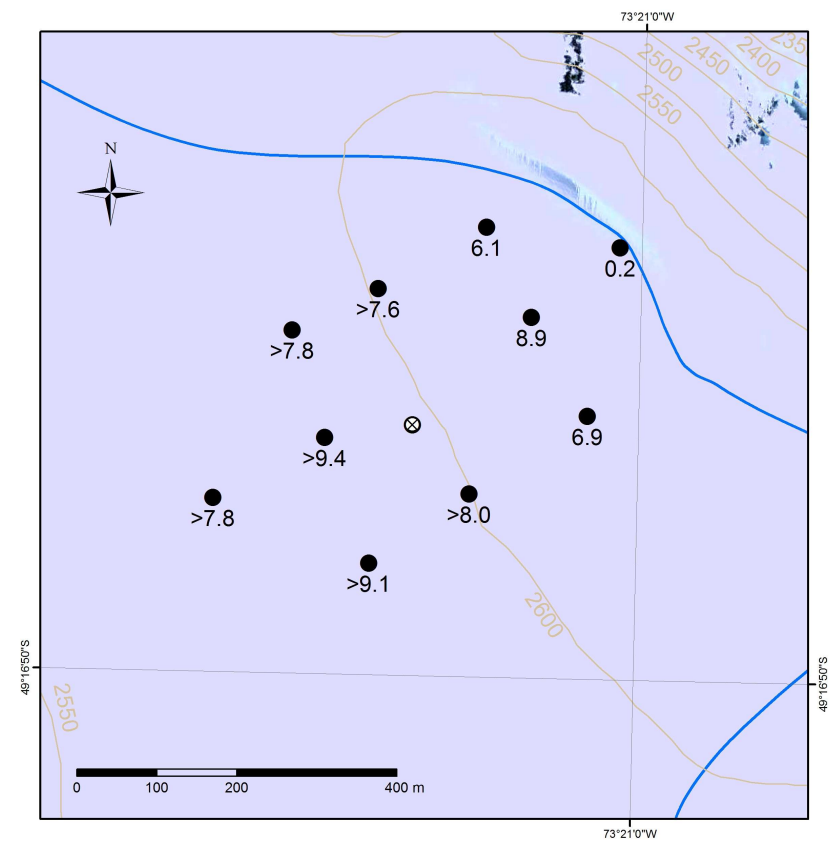

Fig. 7. Stake network (solid black circles) deployed around the drilling site (empty circle with $x$ ). The numbers at each stake represent snow accumulation in $\mathrm{cm} /$ day. The thick blue line shows the location of a prominent ridge which marks the ice divide between Pío XI Glacier and Viedma Glacier to the north and to the east. The brown lines are contour lines with elevations in ma.s.l., obtained from the SRTM 2000 data. All stakes located lower than $2600 \mathrm{~m}$ were lost due to snow burial, showing a snow accumulation larger than $7 \mathrm{~cm} \mathrm{day}^{-1}$. At the highest stake, snow accumulation was practically zero, which is due to enhanced wind in the proximity of the ridge. The background image is a Quickbird scene of 26 December 2004, obtained from Google Earth, which shows a crevasse immediately northeast of the ridge, and some rock outcrops farther downslope.

Table 1. Net annual accumulation at Pío XI for the individual years for the period February 1-31 January.

\begin{tabular}{lrrrrr}
\hline Year & 2005 & 2004 & 2003 & 2002 & 2001 \\
\hline $\begin{array}{l}\text { Accumulation } \\
\text { (m weq) }\end{array}$ & 6.0 & 6.5 & 5.8 & 7.1 & 3.4 \\
\hline
\end{tabular}

summer season can be explained by the fact that trees do not flower regularly and in some years widespread non-flowering occurs. Thus, the pollen records alone do not allow dating, but they confirm the identification of annual layers based on stable isotopes.

The proposed dating results in high annual net accumulation rates of 3.4-7.1 m weq, with an average of $5.8 \mathrm{~m}$ weq (Table 1). Note that a year represents the period 1 February to 31 January. This does not induce a major uncertainty since accumulation is evenly distributed throughout the year, see below. The obtained accumulation was not corrected for 


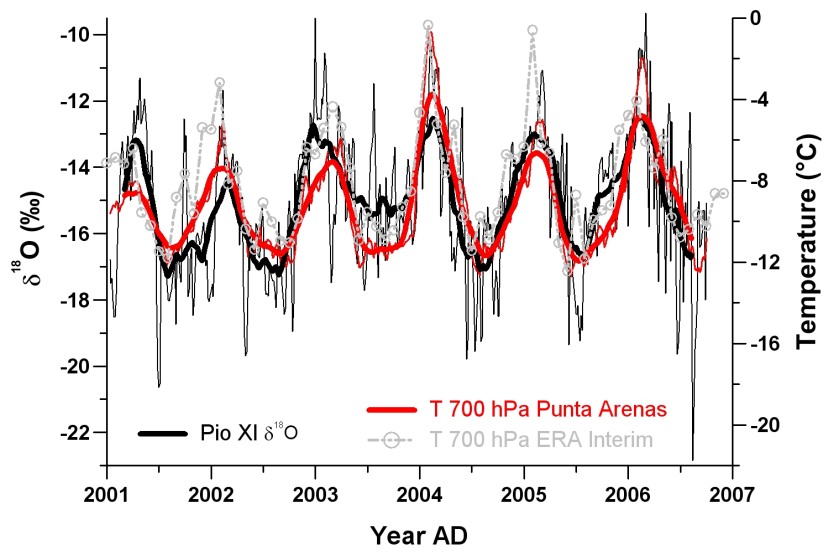

Fig. 8. Pío XI $\delta^{18} \mathrm{O}$ record (thin black line: raw dataset adjusted to 100 points per year, thick black line: 29 point moving average) compared to $700 \mathrm{hPa}$ temperature data from Punta Arenas (thin red line: daily raw dataset adjusted to 100 points per year, thick red line: 29 point moving average) and to $700 \mathrm{hPa}$ temperature reanalysis data from ERA-Interim (grey dashed line, monthly values, nearest grid point $49.50^{\circ} \mathrm{S}, 73.50^{\circ} \mathrm{W}$ ). For procedure to transform ice core depth scale in time scale see text.

thinning due to glacier flow, since a Nye type model (Nye, 1963) showed insignificant thinning in the upper part of the glacier discussed here. This finding is consistent with data from other alpine glaciers, where the thinning is minor above $50 \mathrm{~m}$ (see e.g. Schwerzmann et al., 2006; Knüsel et al., 2003). The average net accumulation rate at Pío XI is comparable to precipitation amounts at the Chilean coast, but not as high as the $10 \mathrm{~m}$ weq expected for the Icefield (Carrasco et al., 2002). Erosion due to wind drift is a relevant factor that affects snow accumulation, as was detected in the field based on stake observations during the two weeks campaign between 16 August and 2 September 2006 (Fig. 7). The drilling site, located on a high plateau only $300 \mathrm{~m}$ from a prominent ridge, is exposed to very high wind, generally from the west, which effectively reduces the snow accumulation. However, this effect is strongest in the proximity of the ridge, where wind is enhanced, and less pronounced at the drilling site. The amount of snow erosion can not be quantified, thus, we consider the obtained net accumulation rates as lower limits. Since there are very few published accumulation data from the SPI we think our estimation for this location is very valuable. Compared to accumulation rates of 1.2 and $0.36 \mathrm{~m}$ weq deduced from Perito Moreno (Aristarain and Delmas, 1993) and $0.19 \mathrm{~m}$ weq from San Valentín (Vimeux et al., 2008), two other ice core sites at the eastern margin, the net accumulation rate at Pío XI is much higher. This suggests a strong west-east precipitation gradient within the SPI and/or stronger wind erosion effects at Perito Moreno and San Valentín.

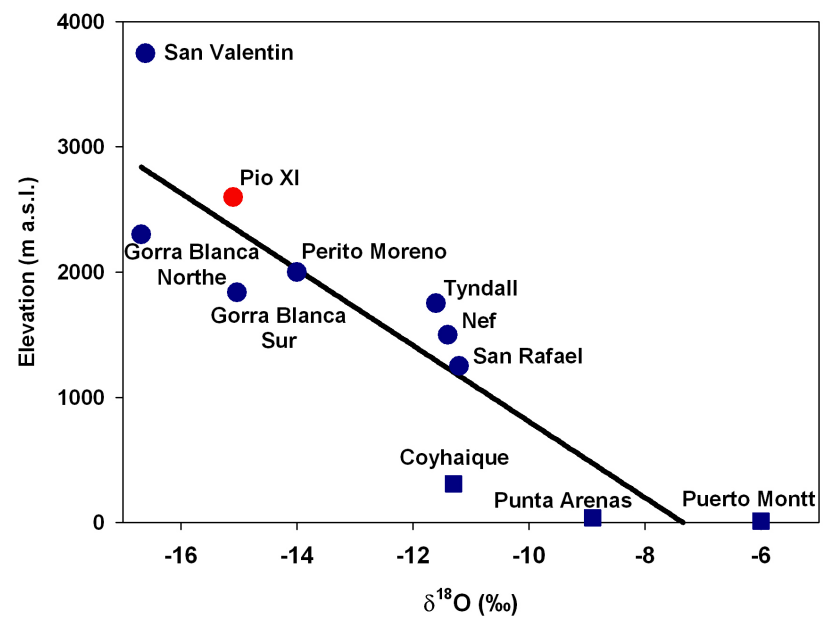

Fig. 9. Mean $\delta^{18} \mathrm{O}$ values as function of elevation compared for different ice cores from SPI and NPI (circles) and nearest GNIP stations (squares). Ice core data from San Valentín, Gorra Blanca, Perito Moreno, Tyndall, Nef, and San Rafael are from (Aristarain and Delmas, 1993; Matsuoka and Naruse, 1999; Schwikowski et al., 2007; Shiraiwa et al., 2002; Vimeux et al., 2008; Yamada, 1987).

\subsection{Relationship between stable isotopes and temperature}

For identifying annual layers, the stable isotope records were used, assuming that they reflect regional temperature. In order to check the potential of $\delta^{18} \mathrm{O}$ and $\delta \mathrm{D}$ as temperature proxy, the records were compared to temperature at $700 \mathrm{hPa}$ (approximately $2850 \mathrm{~m}$ a.s.l.) from upper air radiosonde data collected at Punta Arenas, $460 \mathrm{~km}$ southeast of Pío XI. The depth scale of the ice core was transformed linearly into a time scale starting on 12 December 2000 and ending on 1 September 2006, using the maxima in the stable isotope record, which were assigned to the highest temperature in the Southern Hemisphere summer. This procedure is justified because of the uniform distribution of precipitation throughout the year. All datasets (stable isotope series and air temperature), were averaged to yield three-day means, which represents the lowest resolution in the deepest part of the ice core. Both, $\delta^{18} \mathrm{O}$ and $\delta \mathrm{D}$ data series agree reasonably well with the air temperatures. Pearson correlation coefficients are $r=0.63(p<0.001, n=573)$ for the individual data and $r=0.81(p<0.001, n=19)$ for the 29 point moving averages for the correlation between $\delta^{18} \mathrm{O}$ and temperature (Fig. 8). The corresponding $\delta^{18} \mathrm{O} /$ air temperature ratio of $0.54 \% 0^{\circ} \mathrm{C}^{-1}$ is in good agreement with ratios from the Antarctic Peninsula $\left(0.56 \%{ }^{\circ} \mathrm{C}^{-1}\right.$, Aristarain et al., 1986) and from Argentine Island $\left(0.59 \pm 0.4 \% 0^{\circ} \mathrm{C}^{-1}\right.$, Rozanski et al., 1993). This corroborates that the Pío XI stable isotope composition is mainly controlled by temperature.

It is well known that $\delta^{18} \mathrm{O}$ and $\delta \mathrm{D}$ of precipitation become more negative with increasing altitude (altitude effect). This is attributed to the progressive condensation of atmospheric 
vapour and rainout of the condensed phase when air masses undergo lifting and adiabatic cooling. This dependence was investigated for $\delta^{18} \mathrm{O}$ values of different ice core records from SPI and NPI and the instrumental stations Punta Arenas, Puerto Montt and Coyhaique which belong to the Global Network of Isotopes in Precipitation (GNIP). For the GNIP data, monthly values from 1995-1998 were averaged, because this period was available for all stations (Fig. 9). Assuming a linear relation between altitude and $\delta^{18} \mathrm{O}$ an altitude lapse rate of $0.32 \% \circ 100 \mathrm{~m}^{-1}$ is obtained, comparable to values found in most regions of the world below $5000 \mathrm{~m}$ elevation (Poage and Chamberlain, 2001). The $\delta^{18} \mathrm{O}$ average at Pío XI $(-15.1 \%$ ) agrees well with the stable isotope composition of precipitation at the same altitude at $33^{\circ} \mathrm{S}$ in Chile (Rozanski and Araguas Araguas, 1995) and thus reflects depletion due to orographic lifting and rainout from the Pacific as the dominant moisture source.

\section{Conclusions}

The $50 \mathrm{~m}$ ice core collected from the accumulation area of Pío XI ( $2600 \mathrm{~m}$ a.s.l., $\left.49^{\circ} 16^{\prime} \mathrm{S}, 73^{\circ} 21^{\prime} \mathrm{W}\right)$ is the first core from the Southern Patagonia Icefield, showing well preserved records of stable isotopes throughout. This was expected at the altitude of $2600 \mathrm{~m}$ a.s.l. for which annual mean temperatures in the range of -8 to $-11^{\circ} \mathrm{C}$ were estimated. However, borehole temperatures indicated near-temperate ice, contradicting the good preservation of the stable isotope signals. We assume that most meltwater formed at the surface or rain infiltrating the upper firn layers immediately refroze, forming impermeable ice layers observed in the core and increasing the ice temperature due to latent heat release. Meltwater relocation and drainage cannot be totally excluded, but the amount is limited. Otherwise the stable isotope signals would not be preserved.

Annual net accumulation derived from annual layers identified in the profiles of stable isotopes and biological markers ranged from 3.4-7.1 m weq. These values are similar to precipitation rates at the Chilean coast, much higher than at other high-elevation sites further to the east, but not as high as expected for the Icefield. This suggests that even at the flat plateau of the Pío XI site influence of snow drift and erosion can not totally be excluded, as was observed during some days in the field. Thus, the derived net accumulation rates present lower limits.

A reasonably good correlation of the stable isotope data with upper air temperatures indicates that the Pío XI stable isotopes are controlled by temperature. They also show the expected altitude effect. Thus, the $50 \mathrm{~m}$ Pío XI core contains besides precipitation (net accumulation) a temperature proxy signal (stable isotopes).

Acknowledgements. Special thanks go to the drilling team which did an exceptional job in the field. Precipitation data were kindly provided by Jorge Carrasco, Dirección Meteorológica de Chile. Financial support from National Geographic (Grant No. 7587-04), FONDECYT, Centro de Estudios Científicos (CECs), Valdivia, Chile, and the Swiss State Secretariat for Education and Research SER (Grant No. CJRP-1004) is highly acknowledged. CECs is funded by the Basal fund programme of CONICYT among other grants.

This work is dedicated to the memory of Beat Rufibach, our dear friend and companion, who drilled the ice core at Pío XI and who left us on 11 February 2012.

Edited by: M. Albert

\section{References}

Aniya, M., Sato, H., Naruse, R., Skvarca, P., and Casassa, G.: The use of satellite and airborne imagery to inventory outlet glaciers of the Southern Patagonia Icefield, South America, Photogramm. Eng. Rem. S., 62, 1361-1369, 1996.

Aristarain, A. J. and Delmas, R. J.: Firn-core study from the Southern Patagonia Ice Cap, South-America, J. Glaciol., 39, 249-254, 1993.

Aristarain, A. J., Jouzel, J., and Pourchet, M.: Past Antarctic Peninsula climate (1850-1980) deduced from an ice core isotope record, Climatic Change, 8, 69-89, 1986.

Carrasco, J. F., Casassa, G., and Rivera, A.: Meteorological and climatological aspects of the Southern Patagonia Icefield, in: The Patagonian Icefields: A Unique Natural Laboratory for Environmental and Climate Change Studies, edited by: Casassa, G., Sepulveda, F., and Sinclair, R. M., Kluwer Academic/Plenum Publishers, New York, 29-41, 2002.

Carrasco, J. F., Osorio, R., and Casassa, G.: Secular trend of the equilibrium-line altitude on the western side of the southern Andes, derived from radiosonde and surface observations, J. Glaciol., 54, 538-550, 2008.

Casassa, G., Rivera, A., Aniya, M., and Naruse, R.: Current knowledge of the Southern Patagonia Icefield, in: The Patagonian Icefields: A Unique Natural Laboratory for Environmental and Climate Change Studies, edited by: Casassa, G., Sepulveda, F., and Sinclair, R. M., Kluwer Academic/Plenum Publishers, New York, 67-83, 2002.

Cook, A. J., Fox, A. J., Vaughan, D. G., and Ferrigno, J. G.: Retreating glacier fronts on the Antarctic Peninsula over the past half-century, Science, 308, 541-544, 2005.

Cuffey, K. M. and Paterson, W. S. B.: The Physics of Glaciers, Fourth edition, Elsevier, Burlington, MA, USA, 2010.

Eichler, A., Schwikowski, M., Gäggeler, H. W., Furrer, V., Synal, H. A., Beer, J., Saurer, M., and Funk, M.: Glaciochemical dating of an ice core from upper Grenzgletscher (4200 m a.s.l.), J. Glaciol., 46, 507-515, 2000.

Falvey, M. and Garreaud, R. D.: Regional cooling in a warming world: Recent temperature trends in the southeast Pacific and along the west coast of subtropical South America, J. Geophys. Res., 114, D04102, doi:10.1029/2008jd010519, 2009.

Gehre, M., Geilmann, H., Richter, J., Werner, R. A., and Brand, W. A.: Continuous flow $2 \mathrm{H} / 1 \mathrm{H}$ and and $18 \mathrm{O} / 16 \mathrm{O}$ analysis of water samples with dual inlet precision, Rapid Commun. Mass Sp., 18, 2650-2660, 2004. 
Ginot, P., Stampfli, F., Stampfli, D., Schwikowski, M., and Gäggeler, H.: Felics, a new ice core drilling system for highaltitude glaciers, Workshop "Ice Drilling Technology 2000", Mem. Natl. Inst. Pol. Res. Spec. Issue 56, 38-48, 2002.

Glasser, N. F., Harrison, S., Jansson, K. N., Anderson, K., and Cowley, A.: Global sea-level contribution from the Patagonian Icefields since the Little Ice Age maximum, Nature Geosci., 4, 303307, 2011.

Goto-Azuma, K., Koerner, R. M., and Fisher, D. A.: An ice-core record over the last two centuries from Penny Ice Cap, Baffin Island, Canada, Ann. Glaciol., 35, 29-35, 2002.

Hechenleitner, V., Gardner, M. F., Thomas, P. I., Echeverria, C., Escobar, B., Brownless, P., and Martinez, C.: Plantas amenzadas del centro sur de Chile: Distribución, conservación y propagación, Universidad Austral de Chile y Real Jardın Botanico de Edimburgo, 188 pp., 2005.

Herron, M. M. and Langway, C. C., Jr.: Firn densification: An empirical model, J. Glaciol., 25, 373-385, 1980.

Ibarzabal, T., Donangelo, T., Hoffmann, J. W., and Naruse, R.: Recent climate changes in southern Patagonia, Bull. Glacier Res. 14, 29-36, 1996.

Kerr, A. and Sugden, D.: The sensitivity of the South Chilean snowline to climatic-change, Climatic Change, 28, 255-272, 1994.

Kohshima, S., Takeuchi, N., Uetake, J., Shiraiwa, T., Uemura, R., Yoshida, N., Matoba, S., and Godoi, M. A.: Estimation of net accumulation rate at a Patagonian glacier by ice core analyses using snow algae, Global Planet. Change, 59, 236-244, 2007.

Knüsel, S., Ginot, P., Schotterer, U., Schwikowski, M., Gäggeler, H. W., Francou, B., Petit, J. R., Simões, J. C., and Taupin, J. D.: Dating of two nearby ice cores from the Illimani, Bolivia, J. Geophys. Res., 107, 4181, doi:10.1029/2001JD002028, 2003.

Masiokas, M. H., Luckman, B. H., Villalba, R., Delgado, S., Skvarca, P., and Ripalta, A.: Little Ice Age fluctuations of small glaciers in the Monte Fitz Roy and Lago del Desierto areas, south Patagonian Andes, Argentina, Palaeogeogr. Palaeocl., 281, 351362, 2009a.

Masiokas, M. H., Rivera, A., Espizua, L. E., Villalba, R., Delgado, S., and Aravena, J. C.: Glacier fluctuations in extratropical South America during the past 1000 years, Palaeogeogr. Palaeocl., 281, 242-268, 2009b.

Matsuoka, K. and Naruse, R.: Mass balance features derived from a firn core at Hielo Patagonico Norte, South America, Arct. Antarct. Alp. Res., 31, 333-340, 1999.

Nelson, S. T. and Dettman, D.: Improving hydrogen isotope ratio measurements for on-line chromium reduction systems, Rapid Comm. Mass Sp., 15, 2301-2306, 2001.

Nye, J.: Correction factor for accumulation measured by the thickness of the annual layers in an ice sheet. J. Glaciol. 4, 785-788, 1963.

Oerlemans, J. and Fortuin, J. P. F.: Sensitivity of glaciers and small ice caps to greenhouse warming, Science, 258, 115-117, 1992.

Pelto, M. and Miller, M. M.: Mass Balance of the Taku Glacier, Alaska from 1946 to 1986, Northwest Sci., 64, 121-130, 1990.

Poage, M. A. and Chamberlain, C. P.: Empirical relationships between elevation and the stable isotope composition of precipitation and surface waters: Considerations for studies of paleoelevation change, Am. J. Sci., 301, 1-15, 2001.

Pohjola, V. A., Moore, J. C., Isaksson, E., Jauhiainen, T., van de Wal, R. S. W., Martma, T., Meijer, H. A. J., and Vaikmae, R.:
Effect of periodic melting on geochemical and isotopic signals in an ice core from Lomonosovfonna, Svalbard, J. Geophys. Res., 107, 4036, doi:10.1029/2000JD000149, 2002.

Post, A., O’Neel, S., Motyka, R., and Streveler, G.: A complex relationship between calving glaciers and climate, EOS, 92, 305306, 2011.

Rasmussen, L. A., Conway, H., and Raymond, C. F.: Influence of upper air conditions on the Patagonia icefields, Global Planet. Change, 59, 203-216, 2007.

Rignot, E., Rivera, A., and Casassa, G.: Contribution of the Patagonia Icefields of South America to Sea Level Rise, Science, 302, 434-437, 2003.

Risi, C., Bony, S., Vimeux, F., and Jouzel, J.: Water-stable isotopes in the LMDZ4 general circulation model: Model evaluation for present-day and past climates and applications to climatic interpretations of tropical isotopic records, J. Geophys. Res., 115, D12118, doi:10.1029/2009jd013255, 2010.

Rivera, A. and Casassa, G.: Volume changes on Pío XI glacier, Patagonia: 1975-1995, Global Planet. Change, 22, 233-244, 1999.

Rivera, A., Aravena, J. C., and Casassa, G.: Recent fluctuations of Glaciar Pío XI, Pagagonia: Discussion of a glacial surge hypothesis, Mt. Res. Dev., 17, 309-322, 1997a.

Rivera, A., Lange, H., Aravena, J. C., and Casassa, G.: The 20th Century advance of Glaciar Pío XI, Southern Patagonia Icefield, Ann. Glaciol., 24, 66-71, $1997 \mathrm{~b}$.

Rivera, A., Koppes, M., Bravo, C., and Aravena, J. C.: Little Ice Age advance and retreat of Glaciar Jorge Montt, Chilean Patagonia, Clim. Past, 8, 403-414, doi:10.5194/cp-8-403-2012, 2012.

Rosenblüth, B., Casassa, G., and Fuenzalida, H.: Recent climatic changes in western Patagonia, Bull. Glac. Res., 13, 127-132, 1995.

Rozanski, A. and Araguas Araguas, L.: Spatial and temporal variability of stable isotope composition of precipitation over the South American continent, Bull. Inst. fr. etudes andines, 24, 370390, 1995.

Rozanski, A., Araguas Araguas, L., and Gonfiantini, R.: Isotopic patterns in modern global precipitation, in: Climate Change in Continental Isotopic Records, Geophysical Monograph 78, Am. Geophys. Union, 1-36, 1993.

Santibañez, P., Kohshima, S., Scheihing, R., Jaramillo, J., Shiraiwa, T., Matoba, S., Kanda, D., Labarca, P., and Casassa, G.: Glacier mass balance interpreted from biological analysis of firn cores in the Chilean lake district, J. Glaciol., 54, 452-462, 2008.

Schneider, C., Glaser, M., Kilian, R., Santana, A., Butorovic, N., and Casassa, G.: Weather observations across the Southern Andes at $53^{\circ}$ S, Phys. Geogr., 24, 97-119, 2003.

Schwerzmann, A., Funk, M., Blatter, H., Lüthi, M. P., Schwikowski, M., and Palmer, A. S.: Reconstruction of past accumulation rates in an alpine firn region: Fiescherhorn, Swiss Alps, J. Geophys. Res., 111, F01014, doi:10.1029/2005JF000283, 2006.

Schwikowski, M., Brütsch, S., Casassa, G., and Rivera, A.: A potential high-elevation ice-core site at Hielo Patagonico Sur, Ann. Glaciol., 43, 8-13, 2006.

Shiraiwa, T., Kohshima, S., Uemura, R., Yoshida, N., Matoba, S., Uetake, J., and Godoi, M. A.: High net accumulation rates at Campo de Hielo Patagonico Sur, South America, revealed by analysis of a $45.97 \mathrm{~m}$ long ice core, Ann. Glaciol., 35, 84-90, 2002. 
Thomas, E. R., Dennis, P. F., Bracegirdle, T. J., and Franzke, C.: Ice core evidence for significant 100-year regional warming on the Antarctic Peninsula, Geophys. Res. Lett., 36, L20704, doi:10.1029/2009GL040104, 2009.

Uetake, J., Kohshima, S., Nakazawa, F., Suzuk, K., Kohno, M., Kameda, T., Arkhipov, S., and Fujii, Y.: Biological ice-core analysis of Sofiyskiy glacier in the Russian Altai, Ann. Glaciol., 43, 70-78, 2006.

Villalba, R., Lara, A., Boninsegna, J. A., Masiokas, M., Delgado, S., Aravena, J. C., Roig, F. A., Schmelter, A., Wolodarsky, A., and Ripalta, A.: Large-scale temperature changes across the southern Andes: 20th-century variations in the context of the past 400 years, Climatic Change, 59, 177-232, 2003.

Vimeux, F., de Angelis, M., Ginot, P., Magand, O., Casassa, G., Pouyaud, B., Falourd, S., and Johnsen, S.: A promising location in Patagonia for paleoclimate and paleoenvironmental reconstructions revealed by a shallow firn core from Monte San Valentín (Northern Patagonia Icefield, Chile), J. Geophys. Res., 113, D16118, doi:10.1029/2007JD009502, 2008.

Vimeux, F., Maignan, F., Reutenauer, C., and Pouyaud, B.: Evaluation of cloudiness over Monte San Valentín, Northern Patagonia Icefield, from 2000 to 2008 using MODIS satellite images: implications for paleoclimate investigations from ice cores, J. Glaciol., 57, 221-230, 10.3189/002214311796405915, 2011.
Warren, C. R. and Rivera, A.: Nonlinear climatic response of calving glaciers - a case-study of Pío-Xi Glacier, Chilean Patagonia, Revista Chilena De Historia Natural, 67, 385-394, 1994.

Warren, C. R. and Sugden, D. E.: The Patagonian Icefields - a glaciological review, Arctic Alpine Res., 25, 316-331, 1993.

Willis, M., Melkonian, A., Pritchard M., and Rivera, A.: Ice loss from the Southern Patagonian Ice Field, South America, between 2000 and 2012. Geophys. Res. Lett., 39, L17501, doi:10.1029/2012g1053136, 2012.

Yamada, T.: Glaciological characteristics revealed by 37.6-m deep core drilled at the accumulation area of San Rafael Glacier, the Northern Patagonia Icefield, Bull. Glac. Res., 4, 59-67, 1987.

Yoshimura, Y., Kohshima, S., Takeuchi, N., Seko, K., and Fujita, K.: Himalayan ice-core dating with snow algae, J. Glaciol., 46, 335-340, 2000.

Zhou, S. Q., Nakawo, M., Hashimoto, S., and Sakai, A.: The effect of refreezing on the isotopic composition of melting snowpack, Hydrol. Process., 22, 873-882, 2008. 